Religious Studies, Page 1 of 19 @ The Author(s), 2021. Published by Cambridge University Press doi:10.1017/S0034412520000554

\title{
The aloneness argument against classical theism
}

\author{
JOSEPH C. SCHMID \\ Purdue University, 610 Purdue Mall, West Lafayette, IN 47907, USA \\ e-mail: schmi215@purdue.edu \\ R. T. MULLINS \\ University of Helsinki, Yliopistonkatu 4, 00100 Helsinki, Finland \\ e-mail: rtmullins@gmail.com
}

\begin{abstract}
We argue that there is a conflict among classical theism's commitments to divine simplicity, divine creative freedom, and omniscience. We start by defining key terms for the debate related to classical theism. Then we articulate a new argument, the Aloneness Argument, aiming to establish a conflict among these attributes. In broad outline, the argument proceeds as follows. Under classical theism, it's possible that God exists without anything apart from Him. Any knowledge God has in such a world would be wholly intrinsic. But there are contingent truths in every world, including the world in which God exists alone. So, it's possible that God (given His omniscience) contingently has wholly intrinsic knowledge. But whatever is contingent and wholly intrinsic is an accident. So, God possibly has an accident. This is incompatible with classical theism. Finally, we consider and rebut several objections.
\end{abstract}

\section{Introduction}

Classical theism is a model of God that affirms certain unique divine attributes such as timelessness, immutability, simplicity, impassibility, freedom, omniscience, and omnipotence. ${ }^{1}$ The focus of our article is a conflict among three such attributes: simplicity, freedom, and omniscience. We begin by defining these terms, after which we provide both an informal and formal presentation of what we call the Aloneness Argument. Finally, we consider and rebut five objections. 
Let's turn, then, to definitions of the divine attributes at play. We begin with divine simplicity as defined by proponents of classical theism. ${ }^{2}$

Doctrine of Divine Simplicity (DDS): There is no metaphysical or physical composition in God, such that: (i) there is no distinction in God between substance/attribute, essence/existence, form/matter, act/potency, genus/ differentia, agent/action, and essence/accident; and (ii) all of God's intrinsic features are identical not only to each other but to God Himself.

A little unpacking is required. First, the classical theistic tradition affirms that genus, differentia, forms, properties, accidents, essence, and existence are all metaphysical parts. ${ }^{3}$ Classical theists therefore deny that the simple God has any of this metaphysical complexity. ${ }^{4}$ On this understanding, anything intrinsic to but distinct from $\mathrm{S}$ is part of S. ${ }^{5}$

Also central to our investigation are the concepts of intrinsic and extrinsic features. We use 'feature' as a generic term covering any positive ontological item (e.g. properties, attributes, tropes, modes, states, actions, accidents, forms, matter, acts of existence, essences, etc.). Now, a proper analysis of 'intrinsic' and 'extrinsic' is notoriously elusive. We can, however, offer a rough sketch. Intrinsic features characterize things 'in virtue of the way they themselves are', whereas extrinsic features characterize things 'in virtue of their relations' to other things (Lewis (1986), 61). Intrinsic predications of $S$ are true solely in virtue of how $S$ is in itself. Extrinsic predications of $S$ are true at least in part in virtue of something outside $S$ to which $S$ relationally stands. Intrinsic features are either essential to their bearers (e.g. Socrates' humanity) or non-essential (e.g. Socrates' stubbynosed-ness). Following standard contemporary usage of the term, the latter refer to accidents - intrinsic features of S that are only contingently possessed by S. In other words, we use 'accident of S' to refer to intrinsic features of $S$ that $S$ can exist without. Proponents of divine simplicity explicitly deny that God has any accidental features in this sense. ${ }^{6}$ For if God had intrinsic features merely contingently, then (per DDS) God would be contingent, since God is identical to his intrinsic features. Thus, classical theism requires that accidents - as we have defined them above - cannot accrue to God.

We distinguish, further, between wholly extrinsic features and partly extrinsic features. Roughly, S has F wholly extrinsically provided that the proposition 'S has $\mathrm{F}^{\prime}$ is true solely in virtue of something outside S. S has F partly extrinsically provided that the proposition ' $\mathrm{S}$ has $\mathrm{F}$ ' is true partly in virtue of something outside $\mathrm{S}$ and partly in virtue of S itself.?

Another aspect of classical theism that plays a central role in our argument is God's creative freedom in actualizing the world. Following the lead of proponents of divine simplicity, we characterize this as follows. ${ }^{8}$

Divine Creative Freedom: God is free to create or not create the non-God world, where the non-God world is anything with positive ontological status distinct from God. 
Finally, we also rely on classical theism's commitment to God's omniscience.

Divine Omniscience: Necessarily, God knows everything that exists, obtains, and is true.

Now, it is beyond the scope of this investigation to give an exhaustive and fully detailed characterization of other classical theistic commitments such as timelessness, immutability, and impassibility (and others have offered detailed analyses elsewhere $^{9}$ ). Nevertheless, we've given a faithful and sufficiently precise characterization for the purposes of our argument. In the next section, we set the stage for the Aloneness Argument.

\section{Aloneness of God and contingency of creation}

Classical theism affirms that God could have been alone. Classical theism not only says that it is possible that God exist alone, but that there is in fact a state of affairs wherein God exists alone, ontologically prior to creation. ${ }^{10}$ As Brian Leftow explains, 'before all else existed, God existed, alone, or God and only God did not begin to exist' (Leftow (2012), 4). For our purposes, we highlight the classical theistic claim that there's some possible world wherein God is the only thing in reality. Indeed, this follows straightforwardly from Divine Creative Freedom. ${ }^{11}$ If God is free to create or not create the non-God world, then God could have existed alone - without any non-God thing whatsoever.

One might worry that this only follows if there aren't necessarily existent, uncreated, Platonic abstracta. But Platonism is not compatible with classical theism. ${ }^{12}$ Classical theism demands that anything apart from God has its being sourced in God. ${ }^{13}$ The existence of any non-God thing presupposes God's creation of said thing. As Gaven Kerr emphasizes, for Aquinas and the classical theistic tradition at large, God 'is the unique subsisting source of being from which all existing things come' (Kerr (2019), 15), and creation is understood with 'God as primary source of all things without Whose creative activity there would be nothing' (ibid., 44). Classical theism, then, is explicit that anything distinct from God requires its being to be sourced in God's creative activity.

So, since there being anything apart from God presupposes God's creative activity, and since God is perfectly free to refrain from creating, it follows that there's a possible world wherein God exists alone. Call any world in which God exists alone (i.e. a world in which God freely and providentially chooses not to create) an 'alone world'. So, classical theism entails an alone world is a possible world. Let's call this commitment of classical theism the Aloneness of God. As we shall see, the Aloneness of God undergirds a new argument against classical theism.

Aloneness of God: Possibly, God exists without a non-God world.

The Aloneness of God also entails that the creation of the non-God world is contingent. Call this the Contingency of Creation. 
Contingency of Creation: There is a possible world in which God exists alone, and there are possible worlds in which God exists with a world of non-God things.

We follow the standard understanding of 'contingent' and 'necessary' in our investigation. Something is contingent if and only if it exists (obtains, is true) in some possible worlds but not others. ${ }^{14}$ It could have failed to exist. Something is necessary if and only if it exists (obtains, is true) in all possible worlds. It could not have failed to exist. As applied to things that are not metaphysically impossible, these two metaphysical categories are mutually exclusive and logically exhaustive. ${ }^{15}$

We also stress that suppositional necessity/possibility/impossibility do not threaten our argument. Even if creation is suppositionally necessary, this only means that creation necessarily follows from (i.e. is entailed by) some prior condition. But classical theists are explicit that this prior condition is contingent: it is God's free choice to create - a choice which He genuinely could have refrained from making. ${ }^{16}$ And had God so refrained, God would have existed alone. Therefore, God could have existed alone, even if creation is suppositionally necessary. So, the appeal to suppositional necessity does not avoid the Aloneness of God and, consequently, will not avoid our Aloneness Argument.

Now, the Aloneness of God and Contingency of Creation straightforwardly entail that for each world, there is some contingent truth in that world. This is because for any possible world that you pick, there will be a contingent truth concerning (say) whether God created non-God things. There will also be a contingent truth concerning whether God exists alone. In a world in which God exists alone, it is a contingent truth that God exists alone. It is also a contingent truth in such a world that God freely and providentially chose to refrain from creating. Therefore, according to classical theism, in each possible world there is some contingent truth or other. In other words: necessarily, there is some contingent truth or other. This raises questions about God's knowledge that we address in the next section.

\section{Intrinsic divine knowledge}

Thus far we have established classical theism's commitment to the Aloneness of God, the Contingency of Creation, and the fact that necessarily, there is some contingent truth or other. In this section, we focus on divine knowledge. This will help us reveal an inconsistency among omniscience, simplicity, and creative freedom.

For our purposes at this stage, we leave open the precise way in which God has knowledge. Some models understand it as intrinsic, others as (partly or wholly) extrinsic. We only need the uncontroversial claim that God has knowledge.

Now, on classical theism, some of God's knowledge is such that God necessarily possesses it. But some of God's knowledge is such that God contingently possesses it. ${ }^{17}$ For example, God contingently knows that Earth exists. Since knowledge of $x$ 
logically entails $x$, it follows (by the Distribution Axiom) that if God necessarily knows the Earth exists, then the Earth necessarily exists. But the Earth does not necessarily exist. So, God contingently knows the Earth exists.

Let's consider, next, whether God's knowledge is intrinsic, extrinsic, or a mixture of both. We argue that in the alone world God's knowledge is intrinsic. Historically, classical theists have largely affirmed that God's knowledge is intrinsic to (and in fact identical to) God. ${ }^{18}$ Most non-classical theists also affirm that God's knowledge is intrinsic to God, though they deny that God's knowledge is identical to God (as they deny DDS). Interestingly, some contemporary proponents of classical theism have argued that God's knowledge is extrinsic. ${ }^{19}$ Grant (2012) adopts an extrinsic model of divine knowledge because if divine knowledge were intrinsic to God, then there would be something contingent that is intrinsic to God. This is because God is omniscient and only contingently knows contingent truths. Thus, if divine knowledge were intrinsic to God, then there would be something contingent and intrinsic to God. But that is impossible under classical theism, since anything intrinsic to God is identical to God. God would thereby be identical to something contingent, which is absurd (Grant (2012), 254-257). Our claim, however, is that in the alone world, God's knowledge is wholly intrinsic. Grant's extrinsic strategy of locating (some of) God's knowledge (relationally) outside God, in other words, will not work in the alone world.

In order to get a handle on this issue, consider the following. For any (token or type) feature $\mathrm{F}$ that $\mathrm{S}$ possesses, $\mathrm{F}$ is either wholly intrinsic to $\mathrm{S}$, wholly extrinsic to $S$, or intrinsic to $S$ in some respects but extrinsic to $S$ in others. After all, F either characterizes S as it is in itself, or F doesn't so characterize S. But if F doesn't so characterize $S$, then either $F$ characterizes $S$ only in relation to something else, or $\mathrm{F}$ characterizes $\mathrm{S}$ partly as it is in itself and partly in relation to something else. These exhaust logical space. And from this it follows that God's knowledge is either wholly intrinsic to God, wholly extrinsic to God, or intrinsic in some respects but extrinsic in others.

Consider, next, that S's having the (wholly or partly) extrinsic feature F presupposes that there is something outside $\mathrm{S}$ that serves as a (partial or complete) grounding of S's having F. This simply falls out of the meaning of extrinsic features: they are features $S$ has not solely in virtue of itself - in which case, there must be something apart from S that accounts for S's having them. Without something outside $S$, there would be nothing to which $S$ could relationally stand, and hence there would be no extrinsic features that $S$ could possess.

What follows from the preceding paragraphs is that F can be (i) wholly extrinsic to $S$ or (ii) intrinsic to $S$ in some respects but extrinsic to $S$ in others only if there is something apart from $S$ to which $S$ could relationally stand. And from this it follows that God's knowledge can be (i) wholly extrinsic to God or (ii) intrinsic to God in some respects but extrinsic to God in others only if there is something apart from God to which God could relationally stand. 
But if God exists alone, there is nothing apart from God to which God could relationally stand. Hence, if God exists alone, God's knowledge can be neither wholly extrinsic to God nor intrinsic to God in some respects but extrinsic to God in others. It follows, then, that if God exists alone, then God's knowledge is wholly intrinsic. As we saw earlier, however, the classical theist is committed to the possibility that God exists alone. So, it's possible that God's knowledge is wholly intrinsic. $^{20}$

\section{The aloneness argument}

At this point, the conflict among simplicity, omniscience, and creative freedom arises. If (i) in every world God knows everything that exists, obtains, and is true in that world, and (ii) in every world there are contingent truths, it follows that in every world, God contingently has some knowledge. And (i) follows from Divine Omniscience, and (ii) was established in the previous section. So: necessarily, God contingently has some knowledge. ${ }^{21}$ And since we've already found that it's possible that God's knowledge is wholly intrinsic, it follows that it's possible that God contingently has wholly intrinsic knowledge.

Now, whatever is wholly intrinsic to $S$ is either an essential feature of $S$ or an accident of S. But nothing God contingently has can be an essential feature of God, for then God Himself would be contingent. So, it's possible that God has an accident. But if DDS is true, it's impossible for God to have an accident. God is necessarily simple, lacking in all parts (including accidents). ${ }^{22}$ So, DDS is false.

To put it formally:

1. God's knowledge is either wholly intrinsic to God, wholly extrinsic to God, or intrinsic to God in some respects but extrinsic to God in others.

2. God's knowledge is (i) wholly extrinsic to God or (ii) intrinsic to God in some respects but extrinsic to God in others only if God doesn't exist alone.

3. Possibly, God exists alone.

4. So, possibly, God's knowledge is wholly intrinsic. (1-3)

5. Necessarily, God contingently has some knowledge.

6. So, possibly, God contingently has wholly intrinsic knowledge. $(4,5)$

7. Whatever is wholly intrinsic to $S$ is either an essential feature of $S$ or an accident of $\mathrm{S}$.

8. Nothing God contingently has can be an essential feature of God.

9. So, possibly, God has an accident. (6-8)

10. If $D D S$ is true, it is not possible that God has an accident.

11. So, $D D S$ is false. $(9,10)$

In the following sections, we consider and rebut five objections to the argument. 


\section{Flawed analysis of extrinsicality}

Objection 1. Premise (2) is false because it presupposes a flawed analysis of in/ extrinsicality. The analysis underlying premise (2) holds that a necessary condition for S's having an extrinsic feature is the existence of something wholly apart from (i.e. entirely outside of) S. But this is mistaken, since things can have extrinsic features in worlds in which they exist alone.

Consider a world in which an electron is the only thing in existence (per impossibile). In such a world, the electron has the property of 'existing alone'. But surely this is not an intrinsic property; it is an extrinsic property. An exact duplicate of such an electron may very well lack the property (since the exact duplicate of the electron may exist in a world with protons, say) - in which case it cannot be intrinsic. The electron, in other words, can be deprived of the property without changing anything about the electron itself - the electron can be deprived of the property solely by changing things wholly other than (and entirely outside of) the electron. But in that case, the property cannot be intrinsic to the electron. This is the correct test of in/extrinsicality.

Notice, though, that the electron has this extrinsic property in a world in which the electron exists alone. Thus, the analysis of extrinsicality upon which the Aloneness Argument rests is false - it is not a necessary condition for S's possessing an extrinsic feature that there exist something wholly outside/other than S. Hence, God's contingent knowledge can still be extrinsic in the alone world.

Reply. There are three distinct replies to this objection, each of which we believe is sufficient to avert the objection.

First, note that the proposed counter-example to our understanding of extrinsicality is the property of 'being alone'. But this property reports some absence, lack, or failure of the subject. S's property of 'being alone' reports of S that it fails to exist alongside things outside of (i.e. wholly apart from) S. It reports the absence or lack of non-S things that might co-obtain with $S$.

In general, other proposed counter-examples to our understanding of extrinsicality likewise report some absence, lack, or failure of the subject. Humberstone gives the example of the property 'not being six meters away from any rhododendron' as another paradigm example (Humberstone (1996), 230). These proposed counter-examples are what Lewis $(1983,199)$ calls negative extrinsic properties. They are negative in that they report absences, lacks, or failures of their subjects. Extrinsic properties that don't report such absences, lacks, or failures of their subjects are positive extrinsic properties. Instead of an absence or lack of a relation to something else, positive extrinsic properties are actual relations to something else. $^{23}$

But with this distinction in hand, we can see why Objection 1 does not succeed in averting the Aloneness Argument. For God's knowledge is not a negative property/feature reporting some absence, failure, or lack of God's. In regard to divine 
knowledge, we are talking about some positive reality that God has or possesses. God's knowledge is not an absence, failure, or lack in God in the way that God lacks arms (say) or lacks bad-making properties. Thus, while the objection might show that not all properties of objects in worlds in which they exist alone are intrinsic, it fails to make any headway in showing that God's knowledge is among such properties. Indeed, as we've seen, we have strong reason to reject this. ${ }^{24}$

Second, we think Objection 1 succumbs to a dilemma. Whatever item $x$ we're talking about in a world in which God exists alone, $x$ either has some existence/ reality/positive ontological status, or it doesn't. If $x$ does have some reality, then $x$ cannot be distinct from God, for then $x$ would be created (as any non-God item requires God to create it, under classical theism). But that is impossible, since God doesn't create anything in the alone world. So, $x$ must be strictly identical to God. But then $x$ couldn't contingently obtain, since God is not a contingently obtaining item. On the flip side, if $x$ doesn't have any reality, then anti-realism about $x$ is true.

But now let $x$ be divine knowledge. Classical theists cannot be anti-realists about this, for that would amount to a denial of Divine Omniscience. So, this knowledge has some reality. But if that's the case, then (per our deduction in the previous paragraph) it cannot obtain contingently. We deduced earlier that, in the alone world, any item $x$ with positive ontological status (i.e. with existence or reality) couldn't be contingent. Hence, there cannot be contingently obtaining divine knowledge in the alone world. And that's absurd, since (as we've seen) some of God's knowledge in such a world is merely contingent. ${ }^{25}$

Here's a third reply to Objection 1. Even granting Objection 1's test of intrinsicality, it seems false to say that we could deprive God of knowledge without changing anything about God Himself (and instead solely by changing things wholly apart from and outside of God).

For it seems that one can only know $\mathrm{P}$ if one has justification for believing that P. Hence, God's knowing that P entails that God has justification and belief. Intuitively, though, beliefs - qua mental attitudes towards intentional objects (e.g. propositions, facts, or whatever ${ }^{26}$ )-are such that depriving a conscious subject of them will require changing something about that subject and not just things wholly outside or apart from the subject.

Further, it seems plausible that S's justification must at least partly consist in features of the knowing subject that won't differ solely by changing things wholly outside S. For instance, surely it is partly constitutive of $S$ 's having justification that $S$ is internally consciously aware of one or more reasons upon which $S$ bases S's belief. ${ }^{27}$ It seems, then, that to deprive S of S's justification, one would have to alter the reasons or grounds upon which $S$ bases S's beliefs, alter S's conscious awareness of such grounds, and so on - none of which seem to involve mere alterations to things wholly outside of S. Thus, varying God's knowledge entails varying God's justification, and varying God's justification plausibly cannot be 
done solely by varying things wholly outside of God (i.e. things within the created order).

Moreover, it seems that there's no way to give a principled account of the difference between God's believing a proposition and not believing it (or believing its negation) without some difference within God (as opposed to mere differences in created things wholly outside God). Consider one such proposition, $\mathrm{P}$, which is true in some worlds and false in others. God, then, believes the proposition in some worlds but not in others. What accounts for this? What explains or grounds God's varying beliefs across these worlds?

One might be tempted to say that it's God's differing relations across worlds God's standing in the believing relation in some worlds but not standing in this relation in other worlds - that accounts for it. But there are two problems with this. ${ }^{28}$ First, it doesn't answer the problem but rather relocates it: for in virtue of what does God stand in the believing relation in some worlds but not in others? Without (say) an intrinsic mental attitude towards the propositions that varies from world to world, it's difficult to see what could account for God's standing in these varying relations. Second, this response fails to give a principled way to delineate a belief relation from other relations to propositions in which God stands. For God stands in a whole host of relations to every proposition (existing in the same world as, believing the negation (or affirmation) of, and so on). In virtue of what do some of these relations constitute belief relations while others constitute belief-in-negation relations? The conception of belief as a mere 'believing relation' seems to make God's standing in such relations entirely brute.

Grant (2012) anticipates this grounding worry for an extrinsic model of divine knowledge. He asks us to consider the following propositions:

$P$ : Muggsy Bogues is the shortest player in NBA history.

Q: Spud Webb is the shortest player in NBA history. (Grant (2012), 262)

Grant then asks us to consider a person named Fred who is entertaining these propositions. According to Grant, Fred's act of believing is quite different from God's act of believing. As Grant understands the situation, Fred's act of believing requires a ground, whereas God's does not. Why is a ground required in Fred for his standing in the believing relation to $\mathrm{P}$ instead of $\mathrm{Q}$ ? Grant responds:

\footnotetext{
Presumably, because we need something that accounts for Fred's standing in this relation when it is consistent with being Fred that he stand in the relation to Q instead... Nothing about what Fred is essentially explains why he stands in the believing relation to the true proposition P. So, granting that something must account for his standing in the relation, it looks as if the ground will have to be some intrinsic, accidental property of Fred that he lacks in worlds in which he does not stand in the believing relation to P. (ibid.)
}

Grant explains that, unlike Fred, it's false that nothing about God's essence explains why he stands in such relations. 'God's very essence,' writes Grant, 'is such that he believes whatever propositions are true in any given world. What 
accounts for God's standing in the believing relation to P is simply God's essence coupled with the fact that $\mathrm{P}$ is true' (ibid., 263).

Grant's response here is unconvincing. The very question at issue is (at least in part) how God could be essentially omniscient in the first place provided that (i) there are propositions which are true in some worlds but not in others and (ii) there is nothing (according to DDS) within God that varies across such worlds (like differential awareness, differential mental attitudes, differential internalist justification, and so on). Appealing to omniscience, then, subtly begs the question. The grounding objection to this extrinsic model of God's belief can be rightly understood as an attack on the very notion of essential omniscience given DDS and contingent knowledge. The question is how God could be essentially omniscient in the first place without such intrinsic features that differ from world to world. Grant's solution, then, won't do.

Here's further reason to doubt that Objection 1's test of in/extrinsicality can avert the Aloneness Argument. It seems plausible that (i) truths are such that God desires to know them, and (ii) one cannot change S's desires merely by altering things wholly outside of and apart from S. For desires seem to be essentially mental inclinations or tendencies, and hence they seem to be features that one could change only by changing the subject itself. And it's plausible that God desires to know truths, as possessing knowledge is intrinsically valuable.

Putting all of this together, we can see the following. Because contingent truths vary from the alone world to a non-alone world, it follows by (i) that God's desires vary from the alone world to a non-alone world. And from (ii) in conjunction with Objection 1's test of in/extrinsicality, it would follow that such desires are intrinsic to God (since one cannot deprive God of them merely by altering things wholly apart from/outside of God). Thus, (some of) God's desires will be intrinsic to God in the alone world but yet contingently obtaining. And this is just a desire version of the Aloneness Argument. Hence, Objection 1 fails to avert the Aloneness Argument on yet another score.

One might question at this juncture whether God has desires under classical theism. However, it is a very standard theistic claim that God desires the good and flourishing of human beings. ${ }^{29}$ Moreover, the notion that God has desires and intentions is built into classical doctrines like creation, predestination, and providence. As the classical theist Ron Highfield explains, 'God's act of creating is not irrational or arbitrary but is accompanied by God's intentions and is directed toward an end' (Highfield (2015), 77). When it comes to planning and governing the history of the world, classical theists like Aquinas often talk about God's antecedent and consequent will. God's antecedent will is that all human beings be saved, and that no sin shall occur, whereas God's consequent will is that sin occur, and not all are saved. Leigh Vicens and Simon Kittle point out that concepts like antecedent will are better understood as divine desire because it describes what God wants most in ideal situations. ${ }^{30}$ 
Some classical theists might retort that God has desires only analogously. But our point only requires that God has desires, whether univocally or analogically. For even if God has desires only analogously, he nevertheless desires to know true propositions. And hence if the truth value of (certain) propositions genuinely changes, God's desires - whether analogical or univocal - change.

We've seen a number of plausible reasons why - even granting Objection 1's test of in/extrinsicality - God's knowledge (or God's desire(s) ) will still count as intrinsic in the alone world. Hence, Objection 1 fails to secure extrinsic divine knowledge in the alone world. Thus, it fails to avert contingent, intrinsic items of God in the alone world - that is, it fails to avert the Aloneness Argument. This, in essence, is our third reply to Objection 1.

We believe that these three replies (both individually and collectively) adequately address Objection 1. Let's turn, then, to Objection 2.

\section{Restricted modal collapse}

Objection 2. The classical theist can simply deny premise (3) - the claim that it is possible that God exists alone - and simply accept 'restricted modal collapse': necessarily, God creates, but there is no individual thing which is such that God necessarily creates $i t$. This strategy holds that it is necessary that God create something or other.

Reply. There are several problems with this strategy. To start, classical theists like James Dolezal point out how the necessity of creation is incompatible with classical theism. According to Dolezal, a necessary creation is incompatible with divine absoluteness. If the divine nature is such that God must create, then God depends on the created world's existence in order to be Himself (i.e. fully actual). According to Dolezal, God would need something apart from God to be God - in which case, God wouldn't be absolute. ${ }^{31}$

To further drive home the point that the necessity of creation is not a live option for classical theism, recall that a central commitment of classical theism is the affirmation of divine creative freedom and the Contingency of Creation. Objection 2 aims to avoid the Aloneness Argument, then, by denying classical theism. As a general rule of thumb, we do not advise defending classical theism by way of denying classical theism.

But suppose one abandons classical theism in favour of (say) panentheism to avoid the Aloneness Argument. This might be thought to help because panentheism affirms that God necessarily creates a universe of some sort, though God has some degree of freedom as to which universe God brings about. ${ }^{32}$ Would this help one maintain DDS? We say no for at least two reasons.

First, so long as (i) there's at least one contingent thing, and (ii) intrinsic features of S vary when S's knowledge varies (for justification, see our reply to Objection 1), the existence of a single contingent thing is incompatible with the combination of 
DDS and omniscience. Even ignoring the applicability in this context of our reply to Objection 1, however, problems abound for the necessity of creation response. So, second, even in worlds wherein the non-God world has denizens, it will nevertheless be the case that ontologically prior to God's creative act (i.e. ontologically prior to the contingent world's existence), God contingently had knowledge. For instance, in that ontologically prior state, God knew that <in an ontologically posterior state of reality, contingent object $\mathrm{O}$ exists>. In this ontologically prior state, there existed nothing apart from God, and hence there was nothing (in such a state) to which God could (extrinsically) relationally stand. Ontologically prior to creation, then, (i) God had contingent knowledge, but (ii) such knowledge could not consist in extrinsic relations. And (as we've seen) that means God has accidents, which contradicts DDS. ${ }^{33}$

In concluding this section, we note that even if these replies to Objection 2 fail, we have made a significant discovery: proponents of DDS ought to accept the necessity of creation.

\section{Relations to non-existent things}

Objection 3. The Aloneness Argument assumes that God cannot stand in relations to non-existent things. For if God can stand in relations to non-existent things, then even if God exists alone, His contingent knowledge (or its contents) could consist in extrinsic relations to non-existent contingent things. Premise (2) of the Aloneness Argument, then, is false.

Reply. There are at least four problems with this objection.

First, as with Objection 1, even if this account is correct, it doesn't seem to avoid contingent intrinsic features of God that vary across worlds as God's knowledge varies - and hence it doesn't sidestep the worry about God having accidents. This is because the reasoning employed in Objection 1 (concerning beliefs, justification, awareness, the grounding of belief relations, desires, and so on) in support of this thesis (viz. the thesis that variations in God's knowledge across worlds involve some kind of variation within God) equally applies to Objection 3.

Second, it seems plausible that $x$ can only have a property if $x$ exists. In other words, if $x$ is precisely nothing, then $x$ cannot possess any properties; $x$ cannot be anything unless it exists. How could a non-existent thing-i.e. nothingpossess anything? ${ }^{34}$ But if $x$ 's having $F$ presupposes that $x$ exists, then Objection 3 fails, since the objection at hand presupposes that non-existent things have properties (e.g. the properties being the object of God's knowledge, being within God's awareness, and so on). ${ }^{35}$

Third, Objection 3 seems incompatible with DDS. For under the account in question, (i) God knows non-existent things, but (ii) God does not cause non-existent things (for if God caused them, they would exist!). But if God's knowledge and causal activity were identical, then God's knowing non-existent things would be 
equivalent to God's causing non-existent things. If divine knowing is divine causing, then God causes what he knows. But Objection 3 says that God knows non-existent things without causing them. So, divine knowing is not divine causing. It follows that God's causal activity is not identical to God's knowledge, which is contrary to DDS.

Here is a fourth worry. If we allow non-existent things to function as explanations (explanations of God's contingent knowledge, per Objection 3), then it seems that cosmological (and other explanatory) arguments that demand explanations of broad features of reality (change, contingency, etc.) won't be able to conclude to God's existence. For the explanation could easily be in terms of something non-existent, it seems. Alternatively: we wouldn't have a principled reason for demanding an explanation in terms of an existent entity that wouldn't also serve as a reason to reject Objection 3 .

In concluding this section, we note that even if these replies fail, we have nevertheless made an important discovery: proponents of classical theism ought to give up some highly plausible principles concerning non-existent things. We suspect that many proponents of classical theism would prefer to avoid such commitments.

\section{Content essentialism}

Objection 4. The Aloneness Argument assumes content essentialism, which is the view that the content of a belief or knowledge is an essential feature of that belief or knowledge. ${ }^{36}$ For if content essentialism is false, then God can have one and the same intrinsic state of knowledge across all possible worlds despite different contents of that knowledge across worlds. So, premise (5) is false. It's false that God contingently has knowledge.

Reply. There are at least three problems with this objection.

First, as with Objection 1, even if this account is correct, it doesn't seem to avoid contingent intrinsic features of God - and hence it doesn't sidestep the worry about God having accidents. This is because even if God's knowledge remains the same despite differential contents of that knowledge, God will still (plausibly) have differential justification, differential mental attitudes toward different content, differential awareness of reasons and the relations between reasons and what they justify, differential desires concerning such contents, and so on.

Second, a significant number of philosophers (including ourselves) find content essentialism extremely plausible. Indeed, it's difficult to see how the following two conjuncts could both be true: (i) the object of knowledge is contingent, but (ii) the knowing of that object isn't contingent. For if the object is contingent, it follows that there's some world wherein that object doesn't obtain. And if the object doesn't obtain, it follows that the subject's knowing the object doesn't obtain (since knowledge of $x$ presupposes $x$ 's truth or obtaining). And if that's right, 
then 'the knowing of the object' is contingent so long as the object known is contingent. And again, this knowledge is either intrinsic, partly intrinsic and partly extrinsic, or wholly extrinsic. But in the alone world, it could only be wholly intrinsic. An accident of God, then, is not avoided.

Third, Objection 4 doesn't solve the problem but merely relocates it: for the problem re-arises concerning the ontological status of the content of God's knowledge. In particular, this content is either wholly intrinsic, partly intrinsic and partly extrinsic, or wholly extrinsic. But in the alone world, it cannot be the latter two, for there is nothing apart from God in such a world that could serve as content. ${ }^{37}$ Hence, the content is wholly intrinsic to God. But the content is contingent, which is granted in Objection 4. So, God has an accident in the alone world.

Finally, even if all our replies fail, we have nevertheless made an important discovery: proponents of classical theism ought to give up content essentialism. This will be unpalatable for many.

\section{Know thyself}

Objection 5. What God knows is the very same thing in every possible world (He knows Himself), and so there is no difference in God across worlds, including the alone world. This is analogous to the Thomistic reply to the problem of creation: God wills the very same thing in every possible world (He wills His own goodness), and so there is no difference in God across worlds, including the alone world.

The classical theist can therefore reject premise (5), the claim that, necessarily, God has some contingent knowledge. On classical theism (so the objection goes), God knows everything by knowing His own essence. So, there need not be anything extrinsic to God in the alone world to which He relationally stands. Nevertheless, He still knows contingent truths by essentially knowing His own essence. This means there is no difference in God across worlds, including the alone world. ${ }^{38}$

Reply. This is a valuable objection. However, we are not convinced that it works. We note at least three problems.

First, we note that Objection 5 is focusing on God in a world in which God exists alone. The claim in Objection 5 is essentially saying that 'God can know contingent things by knowing His essence as imitable in various finite ways.' But this response won't do. Within the classical theistic tradition, classical theists have long been aware of the fact that God's self-knowledge only gives God knowledge of all necessary truths, including knowledge about what is possible. ${ }^{39}$ This is often referred to as God's natural knowledge because it is God's knowledge of His own nature. Natural knowledge does not give God knowledge of what is contingently the case. ${ }^{40}$ God might know His essence as imitable, but that neither means nor entails knowledge of the various ways God's essence is actually imitated (or 
actually not imitated). The former can be gleaned from necessary truths concerning what could possibly exist. But it's precisely because the latter expressly concerns contingent truths that knowledge of the former is categorically insufficient for the latter.

Second, since God's essence is utterly unchanging from world to world, it follows that any knowledge solely based on God's essence is unchanging from world to world. But the contingency of the non-God world means that the nonGod world is not unchanging from world to world. And from this, it follows that any knowledge of the non-God world is not unchanging from world to world. Indeed, this is precisely why some contemporary classical theists have been attracted to extrinsic models of divine knowledge. ${ }^{41}$ But, as we've seen, such models won't work for the alone world, since there is nothing extrinsic to or outside of God in such a world.

Third, even if God knows all truths by or through knowing His own essence, something is still contingent here - whether God's knowledge, or the content of God's knowledge, or what have you. Pinpointing the means by which God contingently knows things (by, say, knowing His essence) does nothing to resolve the modal status of such contingent knowledge. Even if the story is true, it only tells us how God got the knowledge. It doesn't nullify or negate its contingency. So, whether it's the knowledge itself, or the content of the knowledge, or what have you, the contingent item in question must be intrinsic to God, since there is nothing extrinsic to or outside God in the alone world. So long as the thing in question has some kind of positive ontological status in the alone world (which surely we must accept if we are to avoid anti-realism about God's knowledge, or the contents thereof, or what have you), a contingent intrinsic item of God's seems unavoidable. And hence there is something intrinsic to God which is contingent. And, as we've seen, this is not compatible with classical theism.

\section{Conclusion}

Classical theism faces a problem. The problem is that the following four tenets seem to comprise an inconsistent tetrad: DDS, Divine Omniscience, Divine Creative Freedom, and the Aloneness of God. As a tool for exploring this inconsistency, we articulated and defended a novel argument called the Aloneness Argument.

In summary form, the Aloneness Argument proceeds as follows. Under classical theism, it's possible that God exists without anything apart from Him. Any knowledge God has in such a state would be wholly intrinsic. But there are contingent truths in every world, including the alone world. So, it's possible that God (given His omniscience) contingently has wholly intrinsic knowledge. But whatever is contingent and wholly intrinsic is an accident. So, God possibly has an accident. And that's incompatible with DDS. 


\section{Our hope is that the Aloneness Argument serves as a tool for fresh enquiry about the nature of God and His relation to the created world.}

\section{References}

Aquinas, T. (1936) Summa Theologiae (London: Burns, Oates, \& Washbourne).

Augustine, S. (1991) The Trinity (Hyde Park: New City Press).

Bergmann, M. \& Brower, J. E. (2006) 'A theistic argument against platonism (and in support of truthmakers and divine simplicity)', in D. W. Zimmerman (ed.) Oxford Studies in Metaphysics (Oxford: Oxford University Press), 357-386.

Bonaventure (1963) The Works of Bonaventure: The Breviloquium II (New York: St Anthony Guild Press).

Broadie, A. (2010) 'Scotistic Metaphysics and creation ex nihilo', in D. B. Burrell, J. M. Soskice, \& W. R. Stoeger

(eds) Creation and the God of Abraham (Cambridge: Cambridge University Press), 53-64.

Brower, J. E. (2009) 'Simplicity and aseity', in T. P. Flint \& M. C. Rea (eds) The Oxford Handbook of Philosophical Theology (Oxford: Oxford University Press), 105-128.

BRunNer, E. (1952) The Christian Doctrine of Creation and Redemption (London: Lutterworth Press).

Burrell, D. B. (1993) Freedom and Creation in Three Traditions (Notre Dame: University of Notre Dame Press).

Craig, W. L. (2001) God, Time and Eternity. The Coherence of Theism II: Eternity (Dordrecht: Kluwer Academic Publishers).

Dolezal, J. E. (2011) God Without Parts: Divine Simplicity and the Metaphysics of God's Absoluteness (Eugene: Pickwick Publications).

DuBy, S. J. (2016) Divine Simplicity: A Dogmatic Account (London: Bloomsbury).

FAKHRI, O. (forthcoming) 'Another look at the modal collapse argument', European Journal for Philosophy of Religion.

Florio, C. D. \& Frigerio, A. (2019) Divine Omniscience and Human Free Will: A Logical and Metaphysical Analysis (Cham: Palgrave Macmillan).

Frost, G. (2014) 'Aquinas and Scotus on the source of contingency', Oxford Studies in Medieval Philosophy 2 (Oxford: Oxford University Press), 46-66.

GarCiA, L. L. (1992) 'Divine freedom and creation', The Philosophical Quarterly, 42, 191-213.

Goris, H. (2005) 'Divine foreknowledge, providence, predestination, and human freedom', in R. V. Nieuwenhove \& J. Wawrykow (eds) The Theology of Thomas Aquinas (Notre Dame: University of Notre Dame Press), 99-123.

Grant, W. M. (2012) 'Divine Simplicity, contingent truths, and extrinsic models of divine knowing', Faith and Philosophy, 29, 254-274.

Grant, W. M. (2019) Free Will and God's Universal Causality: The Dual Sources Account (London: Bloomsbury Academic).

Highfield, R. (2015) The Faithful Creator: Affirming Creation and Providence in an Age of Anxiety (Downers Grove: InterVarsity Press).

Hughes, C. (2018) 'Aquinas on the nature and implications of divine simplicity', European Journal for Philosophy of Religion, 10, 1-22.

Humberstone, I. L. (1996) 'Intrinsic/extrinsic', Synthese, 108, 205-267.

KerR, G. (2019) Aquinas and the Metaphysics of Creation (Oxford: Oxford University Press).

KRETZMAnN, N. (1991) 'A general problem of creation: why would God create anything at all?', in S. MacDonald (ed.) Being and Goodness: The Concepts of the Good in Metaphysics and Philosophical Theology (London: Cornell University Press), 208-228.

Leftow, B. (2012) God and Necessity (Oxford: Oxford University Press).

Leftow, B. (2016) 'Two Pictures of divine choice', in H. J. McCann (ed.) Free Will and Classical Theism: The Significance of Freedom in Perfect Being Theology (Oxford: Oxford University Press), 152-172.

LewIs, D. (1983) 'Extrinsic properties', Philosophical Studies, 44, 197-200.

LewIS, D. (1986) On the Plurality of Worlds (Malden: Blackwell).

Lombard, P. (2007) The Sentences Book 1: The Mystery of the Trinity (Ontario: Pontifical Institute of Mediaeval Studies).

Mawson, T. (2018) The Divine Attributes (Cambridge: Cambridge University Press).

Molina, L. D. (1988) On Divine Foreknowledge: Part IV of the Concordia (Ithaca: Cornell University). 
Muluins, R. T. (2016) The End of the Timeless God (Oxford: Oxford University Press).

Muluins, R. T. (2018) 'Why can't the impassible God suffer?', TheoLogica, 2, 3-22.

Muluins, R. T. (2020) 'Divine temporality and providential bodgery', TheoLogica, 5, 1-28.

Muluins, R. T. (forthcoming) 'Classical theism', in J. M. Arcadi \& J. T. Turner (eds) T\&T Clark Handbook of Analytic Theology (New York: T\&T Clark).

Oord, T. J. ed. (2015) Theologies of Creation: Creatio Ex Nihilo and Its New Rivals (New York: Routledge).

Pruss, A. R. (2008) 'On Two problems of divine simplicity', in J. L. Kvanvig (ed.) Oxford Studies in Philosophy of Religion (Oxford: Oxford University Press), 150-167.

Pruss, A. R. (2017) 'Divine creative freedom', in J. L. Kvanvig (ed.) Oxford Studies in Philosophy of Religion (Oxford: Oxford University Press), 213-238.

Rogers, K. A. (1996) 'The traditional doctrine of divine simplicity', Religious Studies, 32, 165-186.

Rogers, K. A. (200o) Perfect Being Theology (Edinburgh: Edinburgh University Press).

SKRZYPEK, J. W. (2017) 'A Better solution to the general problem of creation', European Journal for Philosophy of Religion, 9, 147-162.

Stump, E. (2003) Aquinas (London: Routledge).

VAluicella, W. F. (2019) 'Divine simplicity', Stanford Encyclopedia of Philosophy, <https://plato.stanford.edu/ entries/divine-simplicity/>.

Vicens, L. \& KitTLE, S. (2019) God and Human Freedom (Cambridge: Cambridge University Press).

Williams, T. (2013) 'Introduction to classical theism', in J. Diller \& A. Kasher (eds) Models of God and Alternative Ultimate Realities (New York: Springer), 95-100.

\section{Notes}

1. Williams (2013); Mullins (forthcoming).

2. Rogers (1996); Duby (2016), 2.

3. Hughes (2018), 2.

4. Lombard (2007), VIII.3; Bergmann \& Brower (2006), 359-36o.

5. Vallicella (2019); Fakhri (forthcoming).

6. Augustine (1991), VII.10; Rogers (1996), 166.

7. Extrinsic features are (at least partly) relational, but not all relational features are extrinsic. Brower (2009) gives the following examples of the latter: 'God is identical with Himself', 'Socrates chooses to go to the marketplace', and 'Socrates has parts'.

8. Kretzmann (1991), 208; Leftow (2016), 152; Pruss (2017), 213-214.

9. Mullins (2018).

10. Brunner (1952), 14-15; Bonaventure (1963), 69; Burrell (1993), 7; Broadie (2010), 53.

11. Skrzypek (2017), 148.

12. Bergmann \& Brower (2006).

13. Leftow (2012), 20; Grant (2019), 4.

14. We emphasize that nothing in our argument hinges on the appropriateness or potential ontological commitments of possible worlds semantics. We employ it as a useful heuristic, and claims involving possible worlds can be translated to claims involving possibility and necessity operators. Talk of possible worlds has been adopted by many contemporary classical theists and medieval commentators like Katherin Rogers, Alexander Pruss, Norman Kretzmann, Laura Garcia, Paul Helm, and many others.

15. What about things like absolute and suppositional/conditional necessity? These distinctions are orthogonal to the metaphysical modalities we articulated. Consider suppositional necessity. Something is suppositionally necessary just in case it necessarily follows from (i.e. is strictly entailed by) some prior condition (Mullins (2016), 137-138). But that prior condition could easily be contingent (as we've defined it). Hence, the 'suppositionally necessary' thing would likewise be contingent; although it necessarily follows from the prior condition, the prior condition is itself merely contingent, and thus so is the 'suppositionally necessary' thing. Hence, even if creation is suppositionally necessary, it will still be metaphysically contingent (as we've defined contingent). This is because under classical theism, the relevant prior condition for creation is the contingent, freely willed divine creative act (Stump (2003), 100-101). Thus, suppositional necessity is entirely orthogonal to our argument: all we need is that there is some possible world wherein God and God alone exists. And as we showed at the beginning of this section, this 
is an explicit commitment of classical theism. We thank an anonymous referee for bringing this to our attention.

16. For a detailed analysis, see Garcia (1992) and Frost (2014).

17. Grant (2012), 255.

18. Aquinas (1936), I.76 and I.82; Rogers (2000), 27-29.

19. Grant (2012).

20. Could we say God's contingent knowledge consists in a failure of God to stand in an extrinsic relation to something apart from Him? This won't do. For a failure to stand in a relation is just a failure to possess a feature - it's an absence of a feature. But God's knowledge is not a failure of God to possess something; it isn't an absence of a feature in God.

21. We stress that not all of God's contingent knowledge in the alone world is of negative existentials (where a negative existential reports the non-existence of one or more things). There are also positive existentials (i.e. non-negative existentials) God contingently knows. For instance: God contingently knows that God freely and providentially chose to refrain from creating. In this case, the object of God's knowledge is not merely some lack or absence of something in reality (as would be the case of God's contingent knowledge, in the alone world, that (say) the Earth doesn't exist). Instead, the object of God's knowledge is God's free, providential choice.

22. Could God be absolutely simple in the actual world but composite in other worlds? This is incoherent. For then God would not be essentially simple. But then he would be accidentally simple. But that's contradictory: God would be accidentally simple, but (per His simplicity) wouldn't have any accidents whatsoever. So, God would both have and not have accidents, which is absurd.

23. One might object: Consider Smith, a human existing alone (per impossibile). Suppose Smith knows that 'I am alone'. Because Smith can be deprived of this knowledge by changing things wholly outside of Smith (suppose that a virtual particle popped into existence), isn't Smith's knowledge that 'I am alone' extrinsic in such a world? We reply: first, even if (some of) Smith's knowledge in this world is (partly) extrinsic, the extrinsicality consists in a relation Smith bears to some non-Smith thing, viz. the truth or fact that Smith exists alone. Thus, this is not a counter-example to our claim in the paragraph (of the main text) under consideration. (Moreover: unlike Smith, God stands in no relation to some non-God thing in the alone world, since there is no non-God thing in the alone world.) Second, the Smith case is relevantly disanalogous to God. For when we deprive Smith of knowledge in this case, we envisage a scenario in which Smith merely goes from knowing $\mathrm{P}$ to not knowing $\mathrm{P}$. But this is crucially different from going from knowing $\mathrm{P}$ to knowing not-P. The latter involves a kind of truth-tracking status which seems unintelligible apart from either a change in the relation between the knowing subject and the fact that $\mathrm{P}$ or else some change in the knowing subject's intrinsic mental state (like differential awareness, differential justification, etc.).

24. The proposed counter-example is helpful, though, since it clarifies that our understanding/analysis of in/ extrinsicality is restricted to positive features.

25. Here's one (perhaps clearer) way to think about it. God's knowledge exists/obtains. But some such knowledge is only contingently obtaining in the alone world. Hence, there is something with positive reality in the alone world that is contingent. But this is not possible according to CT, since if it has some positive reality or being but is contingent, then it would be created by God. But by definition, nothing is created by God in the alone world.

26. Recall that we have left open the intentional objects of divine knowledge, as different classical theists will fill in the details here in different ways. For ease of exposition, we will henceforth use propositions as stand-ins. But the arguments go through on other understandings of intentional objects as well.

27. What about externalism, the thesis that factors external to the knowing subject can/do confer justification? Well, we only need the claim that God's justification consists (at least in part) in internal conscious awareness of God's reasons or grounds. And surely God is not unaware of the reasons or grounds for His beliefs! One might also raise a potential counter-example here: babies and (many) animals surely have knowledge despite not being consciously aware of one or more reasons upon which they base their beliefs. Even if correct, however, this won't help the classical theist, since such scenarios only arise with subjects whose awareness is finite, limited, and imperfect (e.g. they are not self-conscious or fully rationally developed). But God's awareness is not finite, limited, or imperfect; he is perfectly self-conscious and rational. 
28. Here is a third response we shan't pursue further: the classical theist tradition is explicit that God cannot stand in any real (i.e. extramental or mind-independent) relations with anything distinct from God (Craig (2001), 61-78).

29. Mawson (2018), 46.

30. Vicens \& Kittle (2019), 52.

31. Dolezal (2011), 210.

32. Oord, 2015).

33. One might think that there is no such thing as a state of affairs ontologically prior to creation. But it seems to follow upon the very notion of creation: that which brings something into being is ontologically prior to that which is brought into being. Aquinas himself writes: 'For all creatures before they existed, were possible, not by any created power, since no creature is eternal, but by the divine power alone, inasmuch as God could produce them into existence' (Summa Theologiae I, q9, a2). See also Summa Theologiae I, q46, a1 and Leftow (2012), 4.

34. We can also see this as falling out of a Quinean meta-ontology: if it is the case that $\exists x(\mathrm{~F} x)$, then the value of the bound variable, $x$, exists.

35. This is analogous to discussions concerning presentism and truthmakers. Cf. Florio \& Frigerio (2019), 136144. One might think that things can be related to past and future things despite their non-existence. A couple of notes: (i) a significant number of presentists adopt strategies that avoid relations to past and future objects (either because past- or future-indexed propositions don't require truthmakers, or because they have presently (or timelessly) existing truthmakers, or what have you); and (ii) relations to past and future things seems relevantly dissimilar to the case at hand, since in the case of relations to past and future things, at least they did exist or will exist. By contrast, the non-existent things with which we've concerned ourselves are always precisely nothing - they never did exist, they don't exist, and they never will exist. This seems to make standing in relations to them all the more mysterious.

36. Content essentialism implies that 'for any beliefs (or knowings) $a$ and $b$, if $a$ and $b$ have different content, they are not the same belief (or knowing), and if a belief (or knowing) has a content $p$, there is no world in which the same belief (or knowing) exists without that content' (Grant (2012), 258).

37. And if this is denied, the content essentialism objection reduces to Objection 3 concerning relations to non-existent things.

38. We are grateful to an anonymous referee for bringing this objection to our attention.

39. For extensive discussion and defence of God's natural and free knowledge, see Change to Mullins (2020).

40. Molina (1988), 130-144; Goris (2005), 111.

41. For example, Pruss (2008), Brower (2009), Grant (2012). 